\title{
Disability Inclusion and Disability Awareness in Muslim Society: An Experience of Indonesians Muslim with Disability in Performing Worship
}

\author{
Dini Widinarsih \\ Dept. of Social Welfare, FISIP University of Indonesia \\ Depok 16424, INDONESIA \\ (dini.widinarsih@gmail.com)
}

\begin{abstract}
Islam views that all people are equal before God. The United Nation Convention on the Human Rights of Persons with Disabilities (CRPD) also recognizes that all persons with disabilities $\left(\mathbf{P W D}^{1}\right)$ are entitled without any discrimination to the equal benefit of the law, including, the equal rights of living independently and being included in the community. It means that Islam and the international society recognize the equal right and inclusion of PWD. In contrast, previous research reveals that history has shown that PWD tend to be forgotten in a human rights context, whereas the PWD's inclusion is essential fulfilments of universal human rights. To discuss disability inclusion and disability awareness in Indonesian Muslim society, the author employs the qualitative method that allows the use of personal lived experience as a source of knowledge. Data was collected by unstructured interviews, and analysed using qualitative data analysis. The results reveals that the realities of Indonesian Muslim PWD is still discouraging due to exclusion and negative disability awareness among Muslim society. In conclusion, disability inclusion is closely related to how Muslim society aware that PWD are part of diversity as declared in the Qur'an, the Hadith and guaranteed by the Law Number 8/2016 concerning PWD.
\end{abstract}

Keywords: Disability Inclusion, Disability Awareness, Indonesian Muslim with disability, Diversity, the rights to perform worship, Law Number 8/2016.

\section{INTRODUCTION}

Islam promotes equality as the will of God Almighty and requires mutual respect of fellow human beings. Islam teaches us that everyone deserves love, care, and respect, and this fact does not change when a person is impaired. What really matters is his or her heart and conduct. We are enjoined to be accepting of all people regardless of their disability and

This paper has been presented in the Diversity and Disability Inclusion in Muslim Societies: Experiences from Asia, UIN International Conference, 21 November 2017 in Jakarta, Indonesia

\footnotetext{
${ }^{1}$ The acronym PWD is used throughout this paper to interchangeably refer to a persons or people with disabilities, only as technical issue in the concern of conserving print space. Occasionally, disabled also used to refer PWD.
}

include them amongst us and support them by addressing their needs. [1]

In line with Islam, the CRPD stipulate that all PWD are entitled to the equal benefit of the law without any discrimination. It include among others, the equal rights of living independently (article 3) and the rights of being included in the community (article 19).

The CRPD issued on 13 December 2006, and became fully operational in May, 2008 [2]. The purpose of the CRPD is to promote, protect and ensure the full and equal enjoyment of all human rights and fundamental freedoms by all PWD, and to promote respect for their inherent dignity [3]. It also made PWD legally visible in their societies and at the international level [4].

Indonesia signed the CRPD on March 30, 2007, and ratified it on November 30, 2011[5]. This ratification was enacted in to Law Number 19 of 2011 regarding the Ratification of the CRPD [6]. Then, the CRPD was incorporated into Law Number 8 of 2016 concerning PWD to supersede the Law Number 4 or 1997 concerning Disabled people, which considered no longer appropriate to the paradigm of the need of PWD [7]. This acknowledged that the Indonesian Government took a significant step to strengthen Indonesia's commitment to promoting the human rights of PWD.

Thus, Islam and the international society via the United Nation recognize the equal right and inclusion of PWD. "Centuries ago the Prophet showed us that PWD are part of our society and have their rights to participate fully and equally in all kinds of activities [1].

However, literature reveals that regardless of the country's economic situation, history has shown that PWD tend to be forgotten in a human rights context. They continuously experience inequalities, are subject to violations of dignity, denied autonomy and denied a share of society's resources based on their unexpected 'differentness' [8] [9]. However, the inclusion of PWD is one of the most essential fulfilments of universal human rights [4]. The limitation of the literature are that they are about disability and PWD in a Western context. 
They may not adequately address the lives and experiences of non-Western context, such as Indonesian PWD. Notably, in the existing international academic library database, literature about disability and PWD in non-Western contexts, such as Indonesia, is difficult to locate. Although, actually, there were a number international organisations working within the disability sector in non-Western countries, but this experience is rarely disseminating to the academic community via international publication [10]. Among this scarcity, there are literature about disability in Indonesia concerning inclusive education [11 [12], which based on research with people without disabilities. Obviously, there is lack of reference on the issue of disability inclusion and PWD in Muslim Society such as Indonesia.

The aforementioned facts raise a research question for this paper: how is the reality of disability inclusion and disability awareness in Indonesian Muslim Society, especially as experienced by Indonesian Muslim PWD in performing worship ${ }^{2}$ ?

This paper aims to describe the realities of Indonesian Muslim PWD regarding their need and rights to perform shalat in masjid. ${ }^{3}$

There are two novelties of the paper. First, this intended as a way to surface voice of hidden and unheard people such as Indonesian Muslim PWD, to be a social voice. Second, it expected to fill the lack of documentaries of disability and PWD in non-Western contexts, especially from an unexplored field of disability such as Indonesia Muslim PWD.

\section{METHODS}

This study employed qualitative method that allows the use of subjective experience as a source of knowledge [13]. Reference [14] revealed that this method is strongly demanded by PWD because it provide opportunity to express and contextualise their true feelings. PWD are considered as valuable research participants. It underpinned by fact reported by [15] that "there is a significant lacuna of research evidence which captures the thoughts, feelings and perspectives of PWD themselves". This study considered as

Meanwhile, personal experiences and worldviews are valued and understood as being integral of the knowledge gained in the social work research process [16]. This has contributed to the increasing challenge of changing the role and perspective of social work in the disability sector. Now, an increasingly growing perspective is that "disability is seen as a series of experiences and not as pathological conditions requiring other

\footnotetext{
2 The word shalat is used throughout this paper to refer worship. Shalat is prayer, which every Muslim -mans and women- is required to perform at least five times a day.

${ }^{3}$ Masjid is used throughout this paper to refer mosque, and mushola to refer a small worship place.
}

specialist or medical interventions", and that is "a natural part of the diversity that constitutes the human condition" [17].

This study used purposive sampling to recruit four participants, as inspiring by a case study with four young PWD in India [15]. This also in line with [18] who suggest that a reasonable sample size for qualitative research is "between three and six participants." Furthermore, he emphasized "it is important not to see the higher number as being indicative of 'better work'...the issue is quality, not quantity, and given the complexity of most human phenomena. Successful analysis requires time, reflection, and dialogue" [18].

The primary source of this paper is the personal lived experience of four Indonesian Muslim PWD regarding the issue of the rights to perform shalat in the masjid. All participants are 30-40 year old men with acquired disability, means that they were not living with disability since birth (congenital disability) but acquiring a disability over the course of their lifetime. They have visible physical disabilities related to mobility. Two of them have visual impairment and use white canes as their mobility aids. The other two have physically impaired foot due to cerebral palsy, one use crutches, and the other use a wheelchair.

They were voluntary participate in this study through personal contact and interaction with the author. The author has personal experience of having disabled family members and been studying the issues of disability since 1994 .

Data collection followed the common method used in qualitative research [19] consisting of unstructured interviews, casual observations and interactions. These are conducted during 2010-2011 in Jakarta and Surabaya, Indonesia. However, they are still valid, because the issue is still a problem nowadays.

The data were analysed using a thematic analysis explained by [20]. It consists of grouping data into themes, then examining cases in the study to ensure all manifestations of each theme have been accounted for and compared, and then examining how themes are interconnected.

As an exploratory, descriptive study, this paper followed a qualitative writing guidance as explained in ref. [19], to present an essential description of disability inclusion and disability awareness experienced by Indonesian Muslim PWD in relation to their need performing shalat at the masjid.

\section{RESULTS AND DISCUSSION}

With regard to reality experienced by Indonesian Muslim PWD, the two qualitative themes emerged from the data were: (a) invisibility and (b) inaccessible masjid.

(a) Invisibility 
The participants describe that most Indonesian Muslim PWD have experiences invisibility, as expressed by following comment: "It is difficult to know exactly how many Indonesian Muslim who had physical impairment, moreover other impairment. Indeed, the population of PWD in Indonesia is not easy to describe. There is only estimated number of PWD” (P4, VI). Accordingly, they insisted that this also indicated the reality that their existence were invisible among Indonesian Muslim society. "We are visible as someone different, as not normal, and are inferior to non-disabled people, so that our lives, needs and capacities are being ignored" (P1, VI). "We are being discriminated, and not considered as valued members of society, just because we have physical or mental impairment" (P2, CU).

The participants' perception of invisible are similar to explanation in [21] that "to say that one is "invisible" is to imply that one is not accounted for, not recognized/ misrecognized, not acknowledged/ignored".

Furthermore, one of the most tangible evidence of their invisibility, according to them, is their difficulty for the obligation of shalat. "It's ridiculous to suggest us to shalat at home all the time. It's impossible we live only inside the house for the rest of our lives. Sometimes, we have to shalat at masjid". $\left(\mathrm{P} 4, \mathrm{VI}^{4}\right)$. Moreover, "men are recommended to shalat in the masjid, and women are encouraged (to shalat) in her own house. This is obvious, although I cannot specifically mention the verse of the Qur'an or the Hadits" (P1, VI). Others further explained:

"Ironic, the Masjids seems to be an exclusive place of worship. Originally, it due to located only in certain place. Then, it increasingly built almost everywhere, but mostly they are beautifully built with stairs and ablution facility placed in the basement which also with stairs. It all made difficult to access for us. Thus, Muslims with disabilities are ignored to be able to shalat there independently and intact five-time." (P2, CU).

In addition, some complained: "Does it mean that wheelchair users are unable to shalat in masjid forever in their life? (P3, WU) And others illustrated:

On an occasion with five friends, we stopped at the masjid for the shalat Ashr, due to the time will run out, while we were still far from home. We needed hours to walk around the masjid to find a way for us to enter the wonderful masjid but inaccessible for us who uses crutches and wheelchair users. Finally, we are one by one picked up by the security man in order to do

\footnotetext{
${ }^{4}$ To refer the research participants, this paper is use acronym: $\mathrm{P}$ for Participant; numeric $1-4$ to refer a number of participants in this study, and VI is acronym for visual impairment; WU for wheelchair user, and $\mathbf{C U}$ for crutch user

${ }^{5}$ Hadits: the reports on the Prophet Mohammed's teachings, actions, sayings and deeds
}

ablution in the basement and to shalat inside the masjid. Imagine how troublesome at that time; how tired the security man to help us one by one, going up and down the Masjid, and how uncomfortable we were being imposed into the situation. (P2, CU).

\section{(b) Inaccessible masjid}

The participants' explanation of their invisibility are closely related with the reality of an inaccessible masjid. They demonstrated the existing reality in Indonesia where the more masjids are built magnificently, the more it has stairs. It is inaccessible for Muslim PWD, also for the elderly. This is in line with previous observation by other community member [22] who found that most Indonesian places of worship, including masjid, are inaccessible for PWD.

The reality is in contrast with PWD's rights to live independent and rights to worship, due to they are imposed as dependent on others help when they need to access the masjids/musholas

Actually, the participants have tried to talk to Muslim cleric about the Masjids' inaccessibility, but revealed unexpected and discouraging responses as explained by the following participants:

I have argued with the religious official who said that disabled are not obliged to shalat in the Masjids/musholas, because they considered as sick people who are given dispensation. What a pathetic! I explained to him, "Disabled are not sick people! We live with our disabilities throughout life!" But God creates us with the same rights, we have the same rights to shalat in any Masjids/musholas. (P1, VI)

There are still many Muslim leaders who consider Muslims PWD's difficulty to shalat in the masjids independently and intact five time as a natural consequences of their disability. They are required to be patient and accept all these as the determination of GOD with full obedience and resignation. (P3, WU, \& $\mathrm{P} 2, \mathrm{CU})$

Thus, in striving for accessibility in the masjids, participants are revealed how disability awareness among Muslim leaders or clerics. They still perceive being disabled is equal with sickness, incapacity and restriction so it deserved dispensation, including not obligated to shalat in masjid. This is in line with previous literature explaining disabled in the sick role, where the individual is excused from social obligations, but must follow the instructions of a professional to recover [8]. In some Islamic Asian culture, as reported in [23] based on their secondary data, it is common that disability have associated with sickness. 
However, the participants of this study are objected to this negative awareness, affirming disability not a sickness or disease but a social problem and that PWD have the right to be respected.

In line with this response, there were indication a positive response of the Indonesian Ulama ${ }^{6}$ Council in Yogyakarta, Indonesia to the right of Muslim PWD in their town. They release a circular letter calling on all mosques and musholas in the town to provide disabled people with wheelchair ramps, guiding blocks and handrails as well as accessible toilets [22].

The results of this study of four Indonesian Muslim PWD' personal lived experience regarding their needs and rights to perform shalat in the masjid suggest main findings. These are included the realities of disability inclusion and disability awareness in Indonesian Muslim society are closely interrelated. However, these are still discouraging, and will be elucidated in the following discussion.

\section{Disability inclusion}

With reference to the question of this study, participants conceptualise disability inclusion as being included in the Muslim community without discrimination based on disability. This is in line with the previous study which concluded: "inclusion in society can be seen as a way of life a unique approach of perceiving others, to acting and participating in society" [24].

However, the participants revealed that their physical presence in Indonesia do not guarantee social inclusion. They experiences a discouraging inclusion due to discrimination, in the form of invisibility and inaccessible masjids/musholas in Indonesia. This reality, according to disability studies literature [25] [26] [8] are barriers. There are three kinds of barriers, i.e.: physical, attitudinal, and systemic barriers [27].

Thus, Indonesia Muslim PWD in this study are experiencing barriers to their social inclusion, e.g.:

- Physical barriers in the form of inaccessible masjids with stairs, without ramps or lifts, and without any signs to help Muslims with visual or hearing impairments.

- Attitudinal barriers include, to name a few, ignorance even denial of the same values, rights and needs of Muslims PWD.

- Systemic barriers such as institutional practices, which are insensitive to the issues of disability and Muslim PWD. It convey explicitly or implicitly, and in turn limit opportunities for them from enjoying life in the same ways as other Muslims without disabilities in their societies

\footnotetext{
${ }^{6}$ Ulama is plural of 'Alim to refer Muslim religious scholars.
}

Furthermore, these barriers accordingly reflect an inappropriate disability awareness among Muslim society in Indonesia.

\section{Disability awareness}

The participants conceptualise disability awareness as an acceptance and positive attitude towards disability and Indonesian PWD. This is in line with the previous study, whose participants were non-disabled teachers, which defines disability awareness is "a positive attitude and increased empathy toward people with disabilities" [28].

This current study reveals three realities of negative disability awareness, which underpinning barriers that result in discouraging reality of disability inclusion of Indonesian Muslim with disabilities.

First, the majority of the Indonesian public, including Muslim society, has not accepted Indonesian PWD as a part of the diversity of everyday life. They are perceived as 'invisible', as 'different', and imposed to be patient and accept their disability and all the consequence of the disability as the GOD's determination with full obedience and resignation.

This is in contrast with the real Islamic philosophy toward disability and disabled individuals as stated in the Qur'an and the Hadith. It declare the existence of disabilities as a natural part of human nature [23] not as a curse or a blessing [29]. Thus, Muslim PWD are part of diversity, who share common interest and needs with other members of society.

Second, the majority of the Indonesian public is still uninformed that Indonesian PWD are entitled to inherent rights as citizens and that the public has the obligation and responsibility to provide opportunities for them to enjoy their rights.

Factually, these are guaranteed by the Law of the Republic Indonesia Number 8 of 2016 concerning PWD [7], which include 153 articles covering all areas of life. The rights to freedom to religion stipulates in article 5, 14, and 78 up to 84 . In addition, article 98 also regulate about obligation to provide accessible buildings, including for religious function such as masjids and musholas, and sanctions for whoever fail to provide the facilities as stipulate in the article. Article 143 and 144 also regulate about criminal provision to anybody who prohibiting PWD to obtain their rights, including rights as referred to in article 14 .

This law is sophisticated and more advanced than the CRPD. That is, the CRPD does not specifically stipulate religious rights, while the Law Number 8/2016 strictly regulates religious rights, including the accessibility of places of worship. Thus, it is a forceful foundation for awarenessraising of the religious rights of PWD in Indonesian societies.

Third, the majority of the Indonesian public is still neglectful of the fact that Indonesian PWD have capabilities - despite 
their impairment - due to the false belief that they are incapable, and are beneficiary of altruism.

In contrast, previous study [29] found the Qur'anic principle in surah Al-Baqarah verse 286 indicates that Islam offers relief or permission from certain commands and requirement, but everyone are expected to exert the best of one's individual ability, both in the spiritual and temporal spheres. Meanwhile, Prophet Mohammad said that praying the communal prayer is 27 degrees better than the individual prayer [30]. Both of these are strong reason to support Indonesian PWD's rights to perform shalat $\mathrm{Jemaah}^{7}$ in the Masjid. Also for making adjustment so that masjids/musholas are accessible, and PWD are recognized contributing to the communities, not as objects of religious charity or philanthropy programmes.

Islam approve equality, oppose prejudice, and exclusion of any group of people[1] This stated in the Qur'an, surah Al Hujurat, verse 13, which hold: "the equality of the human dignity, the essential human oneness underlying their outward differentiations and removes any stigma and barrier to full inclusion of people with physical conditions"[29]. This verse emphasizes "all human are equal, their worth not on physical attributes but on their spiritual and deeds, and ALLAH encourages them all to make the best use of God's creation. This creation is God's bounty from which no human is excluded" [31].

However, this study reveals similar findings with [23] that there are gap between the real Islamic philosophy toward disability and disabled individuals and the Muslims' understanding and the way they apply this understanding. These gap underpinning existing reality of disability inclusion and disability awareness of Indonesian Muslim PWD in Muslim society in Indonesia.

\section{Conclusion and recommendation}

As conclusion, disability inclusion in Indonesian Muslim society are still discouraging and unfavorable. PWDs' existence are still invisible in Muslim society and religious discourse among Islamic scholars and clerics in Indonesia. This happening due to most of Muslim's understanding and the way they apply this understanding are different with the real Islamic philosophy as stated in the Al Quran and Hadith.

It is imperative that Indonesian Muslim society is inclusive as response to leading mandate of the Al Qur'an, the CRPD, and the Law Number $8 / 2016$. However, this paper concluded that most of Indonesian Muslim society still not aware these mandate, while disability inclusion is strongly related with disability awareness.

One of illustration, most masjids/musholas has been increasingly established across the country almost without

\footnotetext{
${ }^{7}$ Shalat Jemaah: congregational prayer
}

considering them as members of society who have rights and obligation to shalat in the masjids/musholas independently and intact five prayer times. Thus, the discouraging disability inclusion results from lack of disability awareness among Muslim society in Indonesia.

Therefore, as recommendation, this paper suggest that future researches should be done through collaboration with more participants with diverse type of disabilities, diverse region of Indonesia, and various occupations or professions. This is an actual response to the international disability movement's slogan: "nothing about us without us" [32].

It is crucial to include Ulama and Islamic clerics in these collaboration. This is to get more comprehensive point of views, interpretation, and ideas among Muslim society about disability inclusion as to Al Qur'an, Hadith and the Law Number 8/2016 concerning PWD. In order to accelerate an inclusive worship/religious activities in Indonesian Muslim society, Islamic universities in Indonesia should be pioneering these collaboration. It may begin by following the initiatives of 'Muslim disability awareness'. It has been done in Britain and America to generate avenues to emphasize the society attention, concern, and commitment to equal opportunity for Muslim PWD.

\section{REFERENCES}

[1] H. Guvercin, H. "People with disabilities from an Islamic perspective." Culture \& Society. 2008. Retrieved October 18, 2017 from http://www.fountainmagazine.com/Issue/detail/People-with-Disabilitiesfrom-an-Islamic-Perspective

[2] UN ESCAP. Disability at a glance 2010: a profile of 36 countries and areas in Asia and the Pacific. Retrieved from http://www.unescap.org/ sdd/publications/Disability/Disability-at-a Glance-2010.pdf. 2010.

[3] The United Nation Convention the human rights of person with disabilities and the optional protocol to convention.. (The National Human Rights Commission of Indonesia, Trans.). Yogyakarta, Indonesia: Handicap International Indonesia. 2007

[4] J. Ollerton, and D. Horsfall. "Rights to research: utilising the Convention on the Rights of Persons with Disabilities as an inclusive participatory action research tool.” Disability \& Society, Vol. 28(5), pp.616-630. 2013, doi: 10.1080/09687599.2012.717881

[5] United Nation Treaty, Convention on the Rights of Persons with Disabilities. Retrieved from http://treaties.un.org/Pages/ViewDetails. aspx?src=TREATY\&mtdsg_ no=IV15\&chapter $=4 \&$ lang=en $\quad, 2012$, August 30

[6] Law of the Republic of Indonesia Number 19 of 2011 concerning Ratification Convention on the rights of person with disabilities. Retrieved August 8, 2017 from www.bphn.go.id

[7] Law of the Republic of Indonesia Number 8 of 2016 concerning Persons with disabilities. Jakarta: Ministry of Social Services Republic Indonesia.

[8] D. Pfeiffer, The Conceptualization of Disability. In G. E. May \& M. B. Raske (Eds). Ending Disability Discrimination. Strategies for Social Worker. 2005, pp.25-44). Boston: Allyn and Bacon.

[9] World Health Organization. World report on disability. Geneva: World Health Organization. 2011.

[10] H. Katsui, and M. Koistinen, "The participatory research approach in non-western countries: practical experiences from Central Asia and Zambia." Disability \& Society, Vol. 23(7), pp.747-757, 2008. doi: 10.1080/ 09687590802469248.

[11] D. Afrianty, People with disability: locked out of learning? 2015. Retrieved October 19, 2017 from https://indonesiaatmelbourne.unimelb. edu.au/ author/dina/ 
[12] D. Afrianty and K. Soldatic, Disability inclusive education in Indonesian Islamic education institutions. 2016. Retrieved October 19, 2017 from http://globaldisability.org/2016/09/06/disability-inclusive-educationindonesian-islamic-education-institutions

[13] V. Minichiello, and J.A. Kottler, "The personal nature of qualitative research". In V. Minichiello \& J.A. Kottler. Qualitative journey: student and mentor experience with research. (pp. 1-10). California: SAGE publication. Inc., 2010.

[14] R. Kitchin, "The researched opinions on research: Disabled people and disability research", Disability \& Society, 15(2), 25-47. 2000 doi: 10.1080/09687590025757

[15] N. Singal, "Doing disability research in a Southern context: challenges and possibilities". Disability \& Society, 25(4), 415-426. 2010, doi:10 $.1080 / 09687591003755807$

[16] H. D'Cruz, and M. Jones, Social work research. Ethical and political contexts. London: SAGE Publication. Ltd. 2004.

[17] R. Munford and G. Bennie, "Social work and disability". In M. Connolly and L. Harms (Eds.) Social work. Contexts and practice. $2^{\text {nd }}$ Ed., 2009.

[18] J.A. Smith, P. Flower, and M. Larkin, Interpretative phenomenological analysis. Theory, method and research. London: SAGE Publication, Inc. 2009.

[19] J.W. Creswell, Qualitative inquiry and research design: Choosing among five approaches. Thousand Oaks, CA: Sage Publications, 2013.

[20] V. Braun, \& V. Clarke, "Using thematic analysis in psychology". Qualitative Research in Psychology, Vol.3(2), pp.77-101. 2006.

[21] H. Zitzelsberger, "(In)visibility: accounts of embodiment of women with physical disabilities and differences", Disability \& Society, Vol. 20(4), pp389-403, 2005

[22] K.R. Lestari, Indonesian places of worship inaccessible for disabled people. Mosques and churches are working on making their building more inclusive for people with disabilities. 2016. Retrieved October 19, 2017 from https://www.ucanews.com/news/indonesian-places-ofworship -inaccessible-for-disabled-people/77278

[23] H. Al-Aoufi, N. Al-Zyoud, and N.Shahminan, "Islam and the cultural conceptualisation of disability," International Journal of Adolescence and Youth, vol. 17, No.4, pp.205-219, December 2012.

[24] A.N. Diez, "School memories of young people with disabilities: an analysis of barriers and aids to inclusion", Disability \& Society, Vol. 25(2), pp.163-175, 2010. doi:10.1080/09687590903534346

[25] C. Barnes, and G. Mercer, Exploring disability. Second edition. Cambridge, UK: Polity Press, 2010.

[26] M.J. Oliver, Understanding disability: From theory to practice. New York, NY: St Martin's Press, 1996.

[27] P. Parnes, D. Cameron, N. Christie, L. Cockburn, G. Hashemi, and K. Yoshida, "Disability in low-income countries: Issues and implications." Disability and Rehabilitation, Vol.31, No.14, 2009, pp.1170-1180. doi:10.1080/09638280902773778

[28] L. Columna, L. Lieberman, K. Arndt, S. Yang, Using Online Videos for Disability Awareness. Journal of Physical Education, Recreation \& Dance, Vol. 80(8), pp. 19-24, 2009. Doi:10.1080/07303084.2009. 10598369

[29] M.S. Bazna, and T.A. Hatab, "Disability in the Qur'an." Journal of Religion, Disability \& Health. Vol. 9 (1), pp.5 - 27, 2005.

[30] A. Al-Krenawi, The role of the mosque and its relevance to social work. International Social Work, Vol. 59, No.3, 2016, pp.359-367.

[31] E. Harmsen, Islam, civil society and social work. Muslim voluntary welfare associations in Jordan between patronage and empowerment. International Institute for the study of Islam in the modern world (ISIM). Amsterdam University Press, 2008.

[32] M. Stevenson, "Flexible and responsive research: Developing rightsbased emancipator disability research methodology in collaboration with young adults with Down syndrome." Australian Social Work. Vol.63, No.1, pp. 35-50. 2010 